\title{
Association of bronchiolitis with connective tissue disorders
}

\author{
MARKKU HAKALA, ${ }^{4}{ }^{4}$ PAAVO PÄÄKKÖ,$^{3}$ SEPPO SUTINEN , ${ }^{3}$ \\ ESKO HUHTI, ${ }^{1}$ OLLI KOIVISTO ${ }^{4}$ AND MATTI TARKKA ${ }^{2}$
}

From the Departments of ${ }^{1}$ Medicine and ${ }^{2}$ Surgery, University Central Hospital; the ${ }^{3}$ Department of Pathology, University of Oulu, Oulu; and the ${ }^{4}$ Department of Medicine, Päivärinne Hospital, Finland

SUMmary Among 173 consecutive open lung biopsies, nine gave a histopathological diagnosis of bronchiolitis. Seven of these patients had some connective tissue disorder (CTD), six of whom are presented in this report; two had classical and one possible rheumatoid arthritis (RA), one ankylosing spondylitis, one scleroderma, and one developed classical RA four years after biopsy. Four of the patients were smokers, most suffered from breathlessness and cough. In terms of lung function three patients had obstruction, one both restriction and obstruction and three a decreased diffusion capacity. For control purposes peripheral lung tissue was studied histologically from 24 consecutive smoking patients without CTD who underwent a lobectomy for cancer. Intraluminal plugs and mucosal lymphoplasmocytic infiltration of the bronchiolar walls were more prevalent and abundant in the CTD patients than in the controls $(\mathrm{p}<0.02$ and $\mathrm{p}<0.001$ respectively). Two CTD patients also showed some obliterative bronchiolitis. Corticosteroids were effective in one out of four patients treated. One patient improved and the others did not show any progression during the follow up. The results suggest that smoking alone does not explain the lesions of the small airways found in CTD patients, and that bronchiolitis may be specifically associated with the basic disorder in such cases.

Key words: small airways, lung manifestations, rheumatoid nodules, rheumatoid arthritis, ankylosing spondylitis, scleroderma.

Connective tissue disorders (CTD) are often associated with pulmonary manifestations in the form of interstitial fibrosis, pleurisy, and vascular lesions. ${ }^{12}$ A possible association between rheumatoid arthritis (RA) and obliterative bronchiolitis (OB) has been observed recently, ${ }^{3}$ and there are also reports of bronchiolitis in patients with systemic lupus erythematosus (SLE) ${ }^{4-6}$ and progressive systemic sclerosis (PSS, i.e., scleroderma) ${ }^{7}$ but bronchiolitis has not been described in patients with ankylosing spondylitis (AS). Most of the RA patients having OB have shown a progressive airway obstruction, ${ }^{38-16}$ which has in many cases been fatal. ${ }^{38-14}$

In order to study the association between bronchiolitis and CTD and the clinical course of bronchiolitis in CTD we re-evaluated all cases with a

Accepted for publication 14 February 1986.

Correspondence to Dr Markku Hakala, Department of Medicine, Oulu University Central Hospital, SF-90220 Oulu, Finland. histopathological diagnosis of bronchiolitis from a file of 173 consecutive open lung biopsies.

\section{Patients and methods}

All cases with a histopathological diagnosis of bronchiolitis from a file of 173 consecutive open $\mathcal{N}$ lung biopsies studied from 1974 to 1984 at the Department of Pathology, University of Oulu, were ${ }_{N}$ re-evaluated. Nine such patients were found, seven $\omega$ of whom had CTD. Two of these had classical and one possible RA, one had AS, and one PSS diagnosed on the basis of well established criteria for $\mathbb{D}$ these diseases. ${ }^{17-19}$ In addition, one patient had ${ }^{+}$ developed classical RA four years after lung biopsy. $\frac{T}{0}$ Finally, one female patient was primarily considered $\stackrel{\vec{D}}{\stackrel{D}{*}}$ seropositive RA, but later she developed SLE. This $\frac{\rho}{\Phi}$ case will be presented in a separate paper (Pääkkö et $\stackrel{\Phi}{\varrho}$ al, unpublished observation). 
The open lung biopsies had been taken from the right middle lobe in two cases, the right lower lobe in three, and the left lower lobe in one. The excised tissue had been sent immediately to the pathology laboratory, where specimens for cultures of $\mathrm{Myco}$ bacterium tuberculosis and other bacteria and fungi were taken. Slices from the uninflated tissue were first taken for light microscopy, and the remaining tissue was fixed by injecting buffered $4 \%$ formaldehyde $/ 1 \%$ glutaraldehyde solution into a bronchiole via a needleless syringe and immersing the specimen in the same solution overnight. After fixation additional specimens were taken for light microscopy. Paraffin embedded sections were cut at $5 \mu \mathrm{m}$ and stained with haematoxylin-eosin, van Gieson's, Verhoeff's elastic, Perl's iron, and periodic acid-Schiff stains.

In order to evaluate the effect of smoking on the bronchioles we studied peripheral tissue from 24 consecutive smoking patients without CTD (21 men, three women) who were undergoing a lobectomy or pneumonectomy for cancer.

\section{Case reports}

CASE 1

A 55 year old man was referred to the hospital on 21 May 1979 because of pulmonary infiltrations, having had pleurisy in 1942. He had had seropositive, erosive RA since 1973, which was treated with gold. $\mathrm{He}$ had been a labourer but had stopped working because of RA. He had smoked for over 30 years but had not been exposed to dusts or fumes. He had been hoarse and had experienced exertional breathlessness in the three months before admission. On examination he had active synovitis of the elbows, wrists, knees, and ankles. Serum alkaline phosphatase was raised, $480 \mathrm{U} / \mathrm{l}$, but transaminases were normal. A tuberculin test with 1 TU was positive $(17 \times 16 \mathrm{~mm})$. No diagnostic changes were found in serological virus antibody tests. Mediastinoscopy showed larger than normal lymph nodes in the right tracheobronchial junction, and a biopsy specimen from these showed granulomatous and caseous inflammation. Acid fast bacilli were not found, and antituberculosis treatment was started on 15 June 1979. No response to this or any other antibiotic therapy was observed, and the patient had intermittent fever. Prednisolone treatment was started on 29 August 1979. Within three weeks the infiltrates in the chest radiograph had diminished and almost disappeared, and the antituberculosis drugs were stopped.

CASE 2

A 45 year old female farmer was referred to hospital for open lung biopsy on 14 February 1978 because of respiratory symptoms and pulmonary infiltrates. She had had painful joints treated with chloroquine and salicylates for several years, but no definite RA could be diagnosed in spite of positive rheumatoid factor. She had had diabetes treated with insulin since 1977. She worked in livestock breeding on a farm and had smoked for over 20 years. She had suffered from continuous cough and breathlessness after an influenza-like illness in spring 1977. No eosinophilia was found in the sputum or blood, and no precipitating antibodies to Aspergillus fumigatus, Micropolyspora faeni, and Thermoactinomyces vulgaris could be detected in her serum by the immunodiffusion macrotechnique. Rheumatoid factor was positive (Waaler-Rose 1/500). Antinuclear antibodies (ANA) were not found.

\section{CASE 3}

A 45 year old woman was admitted to hospital in December 1980 with three weeks' history of cough and fever, during which time she had received two courses of antibiotics (ampicillin and doxicycline) without effect. She had never smoked or been exposed to fumes. Seropositive RA had been diagnosed in 1966, and she had been treated initially with hydroxychloroquine. She had received no gold, corticosteriods, or penicillamine. No diagnostic changes were found in virus antibody titres, and a sputum culture showed no pathogens. The diagnosis on admission was pneumonia, and cefotaxime IM was begun.

\section{CASE 4}

A 58 year old civil servant was admitted to hospital in July 1978 because of progressive breathlessness experienced over several months. A bypass operation had been performed on the left lower limb in May 1978 for arteriosclerosis obliterans. He had not been exposed to fumes but had smoked for 40 years. In June 1979 he was admitted again because of progressive breathlessness. He had stopped smoking in February 1978.

On February 1982 he developed a symmetrical swelling, stiffness, and joint pains in the hands and feet. Seropositive RA, showing active synovitis of several joints with nodules below both elbows, was diagnosed in June 1982, and treatment with auranofin was started. In September 1984 the treatment was changed to D-penicillamine and prednisolone because of activation of the joint disease.

CASE 5

A 53 year old carpenter was admitted to hospital in May 1978 because of exertional breathlessness. AS, schizophrenia, and mild hypertonia had been di- 
agnosed many years ago, and he had smoked for $\mathbf{4 0}$ years. Treatment had included a variety of antipsychotic drugs (promazine, perphenazine, amitriptyline, biperiden hydrochloride, and chlorprothixene). Limited motion of the spine and limited chest expansion were found in examination. Syndesmophyte formation and almost totally fused sacroiliac joints were seen in the roentgenogram. The Waaler-Rose, latex, and ANA tests were all negative, and he was positive for HLA-B27.

\section{CASE 6}

The patient, a 55 year old cook, had had cyanosis and pallor of the tips of the fingers on cold exposure since 1970 . Some years later she developed puffiness of the hands in the morning. During the last 10 years these symptoms had gradually worsened. In 1978 she had pleurisy. In 1981 she had had intermittent atrial fibrillation, and on examination because of chest pain a stress electrocardiogram showed ST segment depression. She was regarded as suffering from scleroderma and treated with prednisolone, 10 $\mathrm{mg}$ every second day, from March 1982 onwards. She had been breathless on walking for a year before admission and had a productive cough. She had never smoked or been exposed to fumes. She had finger clubbing and non-pitting tautness of the fingers on admission in October 1983. Synovitis of the interphalangeal joints was found in some fingers, and the skin around the mouth was slightly drawn. The latex test was positive (1/32), but the Waaler-Rose test was negative (1/64). The ANA test showed a speckled pattern of immunofluorescence with a titre of $1 / 640$. The extractable nuclear antigen fraction and anticentromere antibodies were negative. Reduced motility in the lower two thirds of the oesophagus was found in cineradiography. DPenicillamine treatment was started in October 1983.

\section{Results}

SYMPTOMS, SIGNS, AND LABORATORY DATA The symptoms and laboratory data are listed in Table 1. Most of the patients had breathlessness and cough, but only two patients were breathless at rest (cases 4 and 5). White blood cells showed a normal differential count in five cases, while case 1 had $79.5 \%$ neutrophils and $6 \%$ eosinophils. Auscultation of the patients' chests indicated bronchial (case 1), dry inspiratory (cases 3,6 ), or basal rales (cases 4,5 ). The typical inspiratory squeak was not heard in any of the cases.

\section{CHEST ROENTGENOGRAMS}

The roentgenological picture was variable, showing
Table 1 Clinical findings in six patients

\begin{tabular}{|c|c|c|c|c|c|c|}
\hline \multirow[t]{2}{*}{$\begin{array}{l}\text { Clinical findings } \\
\text { before biopsy }\end{array}$} & \multicolumn{6}{|c|}{$\begin{array}{l}\text { Patient } \\
\text { No }\end{array}$} \\
\hline & 1 & 2 & 3 & 4 & 5 & 6 \\
\hline Age (years) & 55 & 45 & 45 & 58 & 53 & 55 \\
\hline $\begin{array}{l}\text { Sex } \\
\text { Connective tissue }\end{array}$ & $\mathbf{M}$ & $\mathbf{F}$ & $\mathbf{F}$ & $\mathbf{M}$ & $\mathbf{M}$ & $\mathbf{F}$ \\
\hline $\begin{array}{r}\text { disease (CTD) } \\
\text { Duration of CTD }\end{array}$ & RA & RA & RA & $\mathbf{R A}^{*}$ & AS & PSS \\
\hline $\begin{array}{l}\text { (years) } \\
\text { Duration of }\end{array}$ & 6 & NA & 14 & - & NA & 13 \\
\hline $\begin{array}{l}\text { symptoms (months) } \\
\text { Symptoms }\end{array}$ & 3 & 9 & 1 & 6 & NA & 12 \\
\hline breathlessness & + & + & - & + & + & + \\
\hline cough & - & + & + & - & + & + \\
\hline fever & + & - & + & - & - & - \\
\hline $\operatorname{ESR}(\mathrm{mm} / 1 \mathrm{st} h)$ & 87 & 22 & 118 & NA & 57 & 25 \\
\hline $\mathrm{WBC} \times 10^{-9} / 1$ & $10 \cdot 4$ & $12 \cdot 8$ & $15 \cdot 5$ & $9 \cdot 7$ & $5 \cdot 5$ & 6.9 \\
\hline
\end{tabular}

Abbreviations: RA=rheumatoid arthritis; $A S=$ ankylosing spon- dylitis; PSS=progressive systemic sclerosis (scleroderma); $+=$ present; $-=$ absent; $N A=$ information not available; $E S R=c$ erythrocyte sedimentation rate; $\mathrm{WBC}=$ white blood cell count.C *The patient developed RA four years after diagnosis of the lung disease.

rapidly appearing large nodular densities (case 1), infiltrates changing in location (case 2), local ground glass shadowing (case 3 ), and reticulonodular shadowing with shrinking of the lower lobe (case 6), or a normal appearance (case 4). Four patients had $\mathbb{Q}$ pleural adhesions (cases 1, 3, 5, 6), and case 5 was also suggestive of a folded lung on the left side.

\section{LUNG FUNCTION TESTS}

Table 2 gives the results of lung function tests before open lung biopsy and in a control examination.

Table 2 Results of lung function tests before open lung biopsy and in a control examination

\begin{tabular}{|c|c|c|c|c|c|}
\hline \multirow{2}{*}{$\begin{array}{l}\text { Patient } \\
\text { No }\end{array}$} & \multirow[t]{2}{*}{ Date } & \multicolumn{4}{|l|}{ Test } \\
\hline & & $V C^{*}$ & $F E V_{l}^{*}$ & $F E V \%$ & $D_{L} C O^{*}$ \\
\hline 1 & $\begin{array}{r}24 \text { May } 1979 \\
2 \text { May } 1984\end{array}$ & $\begin{array}{l}82 \\
83\end{array}$ & $\begin{array}{l}75 \\
66\end{array}$ & $\begin{array}{l}69 \\
64\end{array}$ & $\begin{array}{l}46 \\
68\end{array}$ \\
\hline $\begin{array}{l}2 \\
3\end{array}$ & $\begin{array}{l}15 \text { Feb } 1978 \\
\text { NA }\end{array}$ & 86 & 62 & 60 & NA \\
\hline 4 & $\begin{array}{l}11 \text { Sept } 1978 \\
20 \text { Dec } 1983\end{array}$ & $\begin{array}{l}89 \\
90\end{array}$ & $\begin{array}{l}74 \\
72\end{array}$ & $\begin{array}{l}68 \\
59\end{array}$ & $\begin{array}{l}57 \\
79\end{array}$ \\
\hline 5 & 5 June 1978 & 55 & 61 & 85 & 42 \\
\hline & 30 March 1984 & 50 & 43 & 69 & 60 \\
\hline 6 & $\begin{array}{r}24 \text { Oct } 1983 \\
4 \text { Dec } 1984\end{array}$ & $\begin{array}{l}93 \\
94\end{array}$ & $\begin{array}{l}86 \\
95\end{array}$ & $\begin{array}{l}77 \\
82\end{array}$ & 103 \\
\hline
\end{tabular}

Abbreviations: $\mathrm{VC}=$ vital capacity $; \mathrm{FEV}_{1}=$ forced expiratory volume $\bar{O}$ in one second, $D_{L} c 0=$ lung diffusion capacity for carbon monoxide. $\overrightarrow{\mathbb{D}}$ *The values are presented as percentages of predicted values. FEV $\%=\mathrm{FEV}_{1}$ as a percentage of FVC (forced vital capacity). $\stackrel{\odot}{\circ}$ Predicted values according to Salorinne. ${ }^{20} \mathrm{NA}=$ information not $\bar{\sigma}$ available. 
Three patients had obstruction and one patient both restriction and obstruction. Reduced lung diffusion capacity for carbon monoxide $\left(\mathrm{D}_{\mathrm{L}} \mathrm{co}\right)$ was found in three patients. The lung function tests were normal in case 6 and were not performed in case 3 .

\section{BRONCHOSCOPIC FINDINGS}

Bronchoscopy was performed on three patients, two of whom (cases 1 and 5) showed tracheobronchomalacia and bronchitis and one (case 3) mucosal oedema in a segmental bronchus.

\section{GROSS PATHOLOGY}

In three cases the consistency of the lung was more solid than normal, and in case 1 the lung tissue contained mucopurulent secretion. In the others the tissue was normal.

H ISTOPATHOLOGICAL FINDINGS

Histopathological findings in the six CTD patients and 24 smoking control patients without CTD are shown in Table 3 , and the diagnoses of the CTD patients in Table 4. Intraluminal plugs of mucus and desquamated cells (Fig. 1) and mucosal lymphoplasmocytic infiltration of the bronchiolar walls (Figs 1 and 2) were more prevalent in the CTD patients than in the controls, and lymphoplasmocytic infiltrates were more abundant in all the CTD patients than in those controls who showed inflammation. In fact the inflammatory reaction of the bronchiolar

Table 3 Histopathological findings in six CTD patients and 24 control patients without CTD

\begin{tabular}{|c|c|c|c|}
\hline \multirow[t]{2}{*}{$\begin{array}{l}\text { Histopathological } \\
\text { finding }\end{array}$} & \multicolumn{3}{|c|}{$\begin{array}{l}\text { No of cases in which the } \\
\text { finding was present }\end{array}$} \\
\hline & $\begin{array}{l}\text { Patients } \\
(n=6)\end{array}$ & & $\begin{array}{l}\text { Controls } \\
(n=24)\end{array}$ \\
\hline \multicolumn{4}{|l|}{ Bronchiolar changes } \\
\hline Intraluminal plugs & $5 / 6$ & $\mathrm{p}<0.02+$ & $6 / 24^{*}$ \\
\hline Lymphoplasmocytic infiltration & $6 / 6$ & $p<0.001$ & $5 / 24^{*}$ \\
\hline Obliterative lesions & $2 / 6$ & $p<0.05$ & $0 / 24$ \\
\hline Peribronchiolar fibrosis & $5 / 6$ & NS & $15 / 24$ \\
\hline Peribronchiolar dust & $6 / 6$ & NS & $21 / 24$ \\
\hline \multirow{2}{*}{\multicolumn{4}{|c|}{$\begin{array}{l}\text { Peripheral tissue: } \\
\text { a. Interstitial changes }\end{array}$}} \\
\hline & & & \\
\hline Alveolar wall fibrosis & $4 / 6$ & NS & $11 / 24$ \\
\hline Lobular septal fibrosis & $6 / 6$ & $\mathrm{p}<0.005$ & $3 / 24$ \\
\hline Pleural fibrosis & $6 / 6$ & NS & $12 / 24$ \\
\hline Chronic inflammation & $3 / 6$ & $p<0.01$ & $0 / 24$ \\
\hline \multicolumn{4}{|l|}{ b. Alveolar changes } \\
\hline Carnification & $3 / 6$ & $\mathrm{p}<0.01$ & $0 / 24$ \\
\hline Macrophages & $4 / 6$ & NS & $20 / 24$ \\
\hline Emphysema & $2 / 6$ & NS & $16 / 24$ \\
\hline
\end{tabular}

*The bronchiolar changes in the controls were so slight that a diagnosis of bronchiolitis was not justified in any case.

† Statistical significancies according to Fisher's exact probability test.
Table 4 Histopathological diagnoses of CTD patients

\begin{tabular}{|c|c|c|}
\hline $\begin{array}{l}\text { Patient } \\
\text { No }\end{array}$ & $\begin{array}{l}\text { Basic } \\
\text { CTD }\end{array}$ & Histopathological diagnosis \\
\hline 1 & RA & $\begin{array}{l}\text { Bronchiolitis with some obliterative lesions, } \\
\text { obstructive pneumonitis, rheumatoid nodules, } \\
\text { slight interstitial fibrosis }\end{array}$ \\
\hline 2 & $\mathbf{R A}$ & $\begin{array}{l}\text { Follicular bronchiolitis, } \\
\text { centrilobular emphysema }\end{array}$ \\
\hline 3 & RA & Bronchiolitis with intra-alveolar carnification \\
\hline 4 & RA* & Peribronchiolar fibrosis with slight bronchiolitis \\
\hline 5 & AS & $\begin{array}{l}\text { Bronchiolitis with some obliterative lesions, } \\
\text { centrilobular emphysema }\end{array}$ \\
\hline 6 & PSS & $\begin{array}{l}\text { Bronchiolitis with chronic interstitial } \\
\text { pneumonia (UIP) } \dagger\end{array}$ \\
\hline
\end{tabular}

*The patient developed RA four years after diagnosis of the lung disease.

†UIP usual interstitial pneumonia.

walls in the controls was so slight that we would not make a diagnosis of bronchiolitis in any case. There were also some regular germinal centres within the mucosal lymphoplasmocytic infiltrates in one CTD patient (case 2), i.e., follicular bronchiolitis, and two other cases showed eosinophils among the lymphocytes and plasma cells and one a few

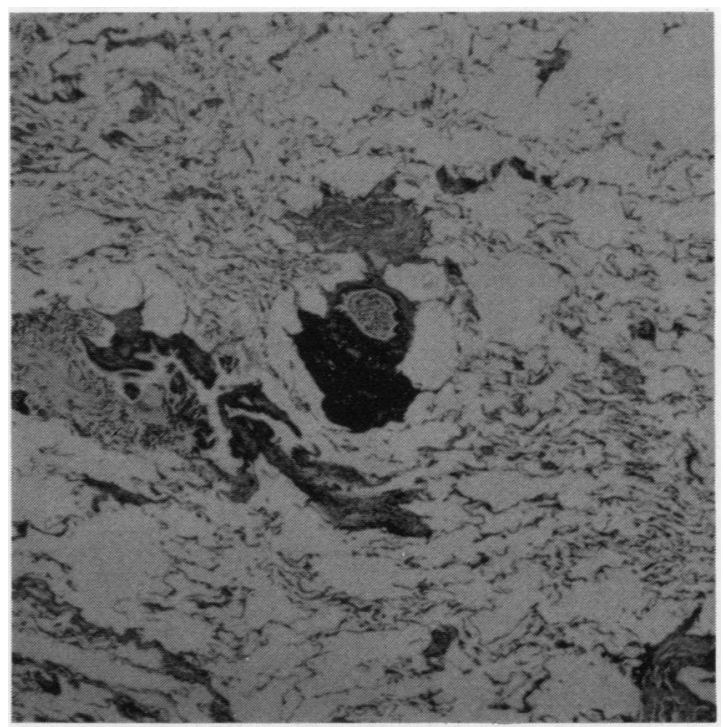

Fig. 1 Light micrograph of an open lung biopsy specimen from a patient with possible rheumatoid arthritis (case 2), showing (centre) a bronchiole with abundant mucosal infiltration of plasma cells and lymphocytes. A plug of mucus and desquamated cells is seen in the lumen, and centrilobular emphysema around the bronchiole. Above this is a pulmonary arteriole with periarteriolar fibrosis. Another longitudinally sectioned inflamed bronchiole is seen to the left. (Haematoxylin and eosin). 


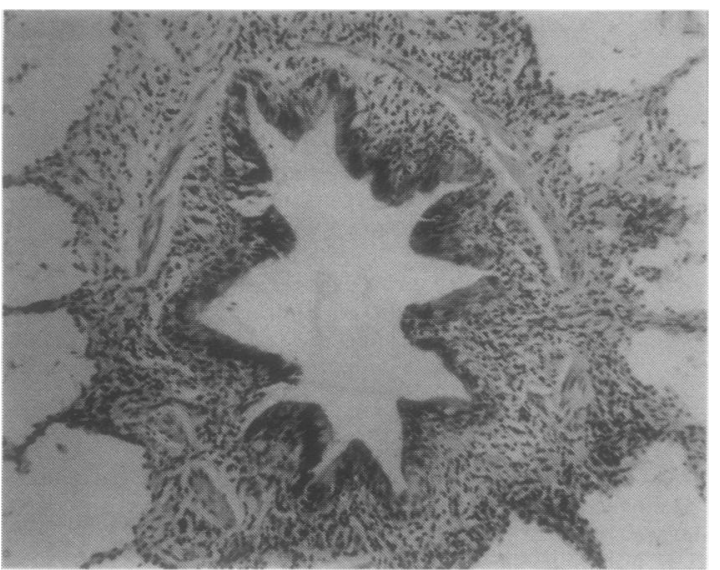

Fig. 2 Light micrograph of an open lung biopsy specimen from a patient with classical rheumatoid arthritis (case 3). showing a bronchiole with a moderate infiltration of plasma cells, lymphocytes, and some eosinophils. A few intraepithelial neutrophils are also visible. (Haematoxylin and eosin).

intraepithelial polymorphonuclear leucocytes (Fig $2)$. Two cases showed some obliterative lesions (Figs 3 and 4).

Lobular septal fibrosis, chronic interstitial inflammation, and intra-alveolar carnification were more prevalent in the CTD patients than in the controls. One CTD patient (case 6) showed a picture of usual interstitial pneumonia (fibrosing alveolitis), and case 1 showed obstructive pneumonitis. The latter case also had rheumatoid nodules (Fig. 5), and case 3 showed signs of abundant intra-alveolar carnification.

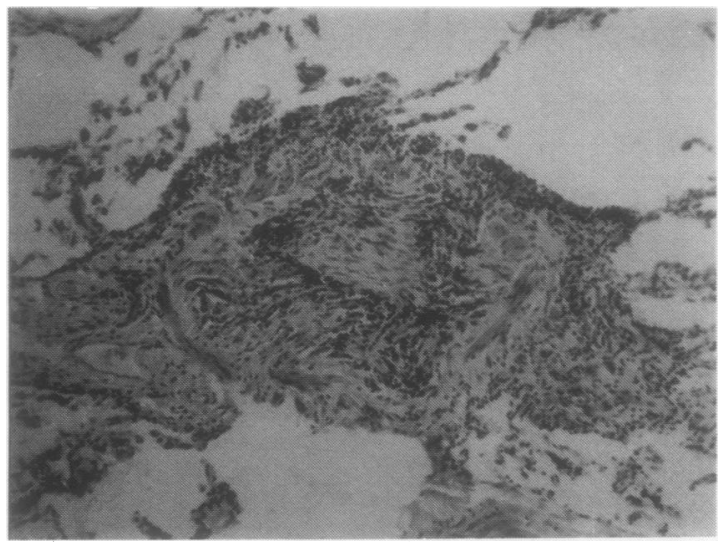

Fig. 3 Light micrograph of an open lung biopsy specimen from a patient with ankylosing spondylitis (case 5), showing obliterative bronchiolitis, i.e., a completely occluded lumen of a bronchiole. (Haematoxylin and eosin).

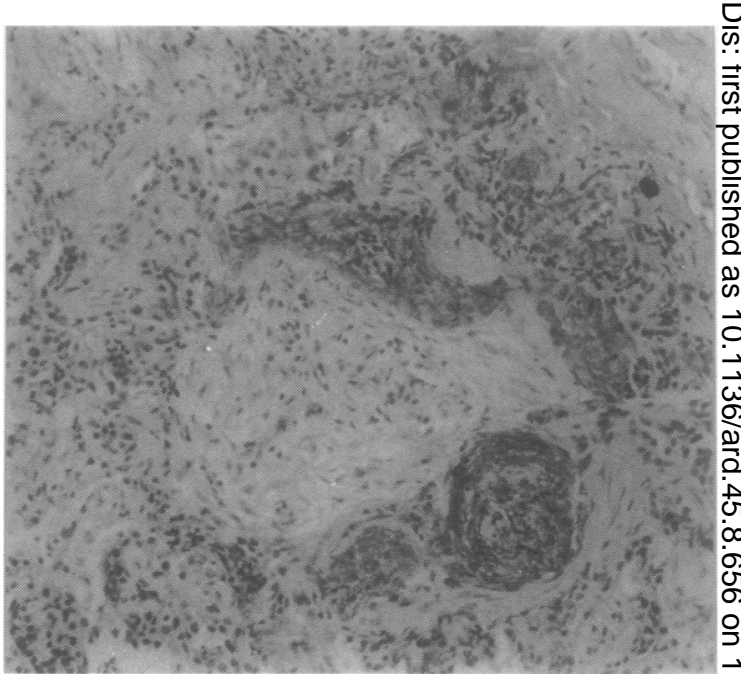

Fig. 4 Light micrograph of an open lung biopsy specimen from a patient with classical rheumatoid arthritis (case 1). showing a totally obliterated bronchiole. The adjacent peripheral lung tissue is infiltrated with inflammatory cells and fibroblasts. (van Gieson's stain).

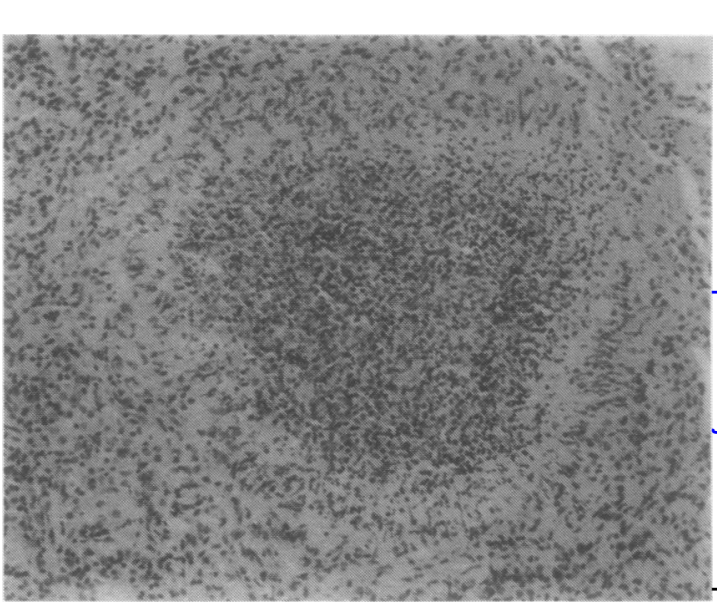

Fig. 5 A rheumatoid necrobiotic nodule from the same patient as in Fig. 4, showing a fibrinoid necrotic centre with o polymorphonuclear leucocytes surrounded by a palisaded layer of histiocytes. (van Gieson's stain).

Cultures of lung tissue for $M$ tuberculosis, other $\stackrel{0}{=}$ bacteria, and fungi were negative in all cases.

TREATMENT AND FOLLOW UP

Four patients (cases $1,2,4,6$ ) were treated with $\stackrel{\vec{D}}{\mathrm{D}}$ corticosteroids, one of them (case 6) primarily for a $\underset{\mathbb{D}}{\stackrel{O}{~}}$ non-pulmonary disease. In only one patient (case 1) 음 did this treatment seem to be effective. One patient 
(case 3), while showing no immediate response to antibiotic therapy, became symptomless and her chest roentgenogram normal after a follow up of four months. The other patients had further respiratory symptoms, but their lung disease had not clearly progressed during the follow up period of one to five years (Table 2).

\section{Discussion}

Bronchiolitis is a rare disease in adults, which has been attributed to inhalation of hydrochloric or nitric acid or occasionally to virus infection, ${ }^{21}$ and a progressive, often fatal, form of $\mathrm{OB}$ in RA is also reported from time to time. ${ }^{3}{ }^{8-16}$ The majority of the cases of OB in RA seem to be associated with D-penicillamine treatment, ${ }^{311-16}$ but otherwise the aetiology is unclear. ${ }^{38-10}$ RA patients may react abnormally to airway inflammation, which tends to progress to airway obliteration after viral or chemical bronchiolitis, ${ }^{322}$ and in such cases D-penicillamine can modify the usual healing process. ${ }^{15}$ Interestingly, none of the CTD patients in our series had been treated with D-penicillamine before the diagnosis of bronchiolitis, though two of them received this medication for their CTD without any evidence of progression in the lung disease.

The studies of small airway function by Collins $e t$ $a l^{23}$ and Geddes $e t a l^{24}$ suggest that milder obstruction of small airways may be common in RA. These observations have not been confirmed by others, ${ }^{2526}$ but there is some pathological evidence to support the existence of milder forms of small airway obstruction in RA. ${ }^{27-29}$ Begin et al describe six rheumatoid patients with slowly progressive obstructive disease of the peripheral airways as an autoimmune manifestation of Sjögren's syndrome. ${ }^{27}$ Interestingly, the histological finding in our CTD patients, i.e., lymphoplasmocytic infiltrations in the bronchiolar walls, was similar to that described by Begin et al, ${ }^{27}$ but none of our patients had Sjögren's syndrome. Herzog et al describe a woman with RA who had multiple pulmonary densities with local bronchiolitis and small subpleural foci of organising pneumonitis, but without any clinical airway obstruction or dyspnoea. ${ }^{28}$ This case, which had a good prognosis, resembled our case 1 clinically but was closer to case 3 histologically. A recent study shows follicular bronchiolitis in RA (like our case 2) with variable prognosis. ${ }^{30}$

Bronchiolar changes are common in chronic bronchitis and emphysema, ${ }^{31}$ and it has been suggested that the obstruction of small airways in RA could be secondary to smoking rather than to $\mathrm{RA},{ }^{26}$ or that the effects of rheumatoid disease and smoking on small airway function are additive. ${ }^{23} 32$
The latter opinion is supported by an experimental study which shows that rheumatoid factor can cause lung lesions in laboratory animals only when there is another ongoing inflammatory process. ${ }^{33}$ Our series, based on a total of 173 consecutive lung biopsies, included nine patients with a diagnosis of bronchiolitis, seven of whom had CTD. Thus bronchiolitis seems to be fairly specifically associated with CTD. Since intraluminal plugs and mucosal inflammatory infiltration of the bronchiolar walls were more prevalent and abundant in our CTD patients than in the control smokers, smoking alone may not explain the small airway lesions in these patients. The significant peripheral changes observed, i.e., lobular septal fibrosis, chronic interstitial inflammation, and intra-alveolar carnification, may partly be explained as being secondary to bronchiolitis.

The lung manifestations of AS are chest wall restriction and upper lobe fibrobullous disease. ${ }^{34}$ We have not found a single case in the literature of AS with OB shown at biopsy, though Spencer states that $\mathrm{OB}$ commonly occurs in $\mathrm{AS},{ }^{35}$ probably basing his conclusions on observations from autopsy material. Our case 5 may well be the first description of bronchiolitis with obliterative lesions in a living patient with AS.

Bronchiolar changes have been reported in usual interstitial pneumonia (UIP) (cryptogenic fibrosing alveolitis) $^{36}$ and UIP associated with connective tissue diseases. ${ }^{37}{ }^{38}$ Our scleroderma patient had UIP, a common lung involvement in scleroderma, ${ }^{39}$ combined with bronchiolitis. UIP was not seen in any others of our CTD patients, however.

\section{Addendum}

Since the preparation of this manuscript one additional report, with a total of 11 patients with bronchiolitis and connective tissue disorders (seven with RA, three with Sjögren's syndrome, and one with AS), has appeared in the literature. ${ }^{40}$

We thank Dr Pekka Ruuska. Department of Medical Microbiology, University of Oulu, for performing anticentromere antibody tests and $\mathrm{Mr}$ Tapio Leinonen. University of Oulu. for preparing the photographs. This study was supported by grants from the $\mathbf{W} \mathbf{J}$ Kaipainen Fund of Oulun Yliopiston Tukisäätiö and the Jalmari and Rauha Ahokas Foundation. Finland.

\section{References}

1 Dunnill M S. Pulmonary pathology. Edinburgh: Churchill Livingstone, 1982.

2 Gibbs A R. Seal M E. Atlas of pulmonary pathology. Ipswich: MTP Press. 1982

3 Geddes D M. Corrin B. Brewerton D A. Davies R J, TurnerWarwick M. Progressive airway obliteration in adults and its association with rheumatoid disease. $Q J$ Med 1977: 46: 427-44. 
4 Matthay R A. Schwarz M I. Petty T L. et al. Pulmonary manifestations of systemic lupus erythematosus. Review of twclve cascs of acute lupus pneumonitis. Medicine (Baltimore) 1974: 54: 397-409.

5 Pertschuk L P. Moccia L F. Rosen Y, et al. Acute pulmonary complications in systemic lupus erythematosus. Am J Clin Pathol 1977; 68: 553-7.

6 Kinney W W, Angelillo V A. Bronchiolitis in systemic lupus erythematosus. Chest 1982; 82: 646-9.

7 Gosink B B. Friedman P J, Liebow A A. Bronchiolitis obliterans. Roentgenologic-pathologic correlation. AJR 1973; 117: $816-32$.

8 Macfarlane J D. Dieppe P A, Rigden B G, Clark T J H. Pulmonary and plcural lesions in rheumatoid disease. $\mathrm{Br} J$ Dis Chest 1978: 72: 288-300.

9 McCann B G, Hart G J, Stokes T C, Harrison B D W. Obliterative bronchiolitis and upper-zonc pulmonary consolidation in rheumatoid arthritis. Thorax 1983; 38: 73-4.

10 Holiness L, Tenenbaum J, Cooter N B E. Grossman R F. Fatal bronchiolitis obliterans associated with chrysotherapy. Ann Rheum Dis 1983; 42: 593-6.

11 Lyle W H. D-Penicillamine and fatal obliterative bronchiolitis. Br Med J 1977; i: 105

12 Murphy K C, Atkins C J, Offer R C. Hogg J C, Stcin H B. Obliterative bronchiolitis in two rheumatoid arthritis patients treated with penicillamine. Arthritis Rheum 1981; 24: 557-60.

13 Jansen H M, Elema J D, Hylkema B S, Leeuwen M A, van der Mark W, Sluiter H J. Progressive obliterative bronchiolitis in a patient with rheumatoid arthritis. Eur J Respir Dis 1982; 63 (suppl): 43-52.

14 Penny W J, Knight R K, Rees A M, Thomas A L, Smith A P. Obliterative bronchiolitis in rheumatoid arthritis. Ann Rheum Dis 1982; 41: 469-72.

15 Epler G R, Snider G L, Gaensler E A, Catchcart E S, FitzGerald M X, Carrington C B. Bronchiolitis and bronchitis in connective tissue disease. A possible relationship to the use of penicillamine. JAMA 1979; 242: 528-32.

16 van de Laar M A F J, Westermann C J J, Wagenaar S, Dinant $H$ J. Beneficial effect of intravenous cyclophosphamide and oral prednisone on D-penicillamine-associated bronchiolitis obliterans. Arthritis Rheum 1985; 28: 93-7.

17 Ropes M W, Bennett G A, Cobb S, Jacox R F, Jessar R A. Revision of diagnostic criteria for rheumatoid arthrits. Bull Rheum Dis 1958; 9: 175-6.

18 Kellgren J H. The epidemiology of rheumatic diseases. Ann Rheum Dis 1964; 23: 109-22.

19 Masi A T, Rodnan G P, Medsger T A Jr, et al. Preliminary criteria for the classification of systemic sclerosis (scleroderma). Arthritis Rheum 1980; 23: 581-90.

20 Salorinne Y. Single-breath pulmonary diffusing capacity. Reference values and application in connective tissue diseases and in various lung diseases. Scand J Respir Dis 1976; suppl 96.

21 Wohl M E B, Chernick V. Bronchiolitis. Am Rev Respir Dis 1978; 118: 759-81.

22 Murphy D M F, Fairman R P, Lapp N L, Morgan W R C.
Severe airway disease due to inhalation of fumes from cleansing agents. Chest 1976; 69: 372-6.

23 Collins R L, Turner R A, Johnson A M, Whitley N O, McLean $\stackrel{\overrightarrow{\mathcal{C}}}{\circ}$ $\mathbf{R} \mathbf{L}$. Obstructive pulmonary disease in rheumatoid arthritis. Arthritis Rheum 1976; 19: 623-8.

24 Geddes D M, Webley M, Emerson P A. Airways obstruction in $\overline{\bar{c}}$ rheumatoid arthritis. Ann Rheum Dis 1979, 38: 222-5.

25 Hyland R H, Gordon D A, Broder I, et al. A systemic controlled study of pulmonary abnormalities in rheumatoid arthritis. J Rheumatol 1983; 10: 395-405.

26 Sassoon C S H, McAlpine S W, Tashkin D P, Baydur A, $\vec{O}$ Quismorio F P, Mongan E S. Small airways function in nonsmokers with rheumatoid arthritis. Arthritis Rheum $1984 ; \vec{\omega}$ 27: $1218-26$

27 Begin R, Masse S, Cantin A, Menard H, Bureau M. Airways disease in a subset of nonsmoking rheumatoid patients. Characterization of the disease and evidence for an autoimmune $A$ pathogenesis. Am J Med 1982; 72: 743-50.

28 Herzog C A, Miller R R, Hoidal J R. Bronchiolitis and rheumatoid arthritis. Am Rev Respir Dis 1981; 124: 636-9. G

29 Lahdensuo A, Mattila J, Vilppula A. Bronchiolitis in rheumatoid arthritis. Chest 1984; 85: 705-8.

30 Yousem S A, Colby T V, Carrington C B. Follicular bronchitis/ bronchiolitis. Hum Pathol 1985; 16: 700-6.

31 Anonymous. Obliterative bronchiolitis [Editorial]. Lancetc 1982 ; i: $603-4$

32 Mountz J D, Turner R A, Collins R L, Gallup K R, Semble E L. Rheumatoid arthritis and small airways function. Effects of $\overrightarrow{0}$ disease activity, smoking, and alpha $a_{1}$-antitrypsin deficiency. Arthritis Rheum 1984; 27: 728-36.

33 DeHoratius R J, Williams R C Jr. Rheumatoid factor accentuation of pulmonary lesions associated with experimental diffuse proliferative lung disease. Arthritis Rheum 1972; 15: 293-301.

34 Hunninghake G W, Fauci A S. Pulmonary involvement in the collagen vascular disease. (State of the art). Am Rev Respir Diso 1979; 119: 471-503.

35 Spencer H. Pathology of the lung. Oxford: Pergamon, 1977: 2.

36 Fulmer J D, Roberts W C, von Gal E R, Crystal R G. Smallo airways in idiopathic pulmonary fibrosis. Comparison of mor- 3 phologic and physiologic observations. J Clin Invest 1977; 60: 595-610.

37 Schwarz M I, Matthay $\mathbf{R}$ A, Sahn S A, Stanford R E, Marmorstein B L, Scheinhorn D J. Interstitial lung disease in polymyositis and dermatomyositis. Analysis of six cases and. review of the literature. Medicine (Baltimore) 1976; 55: 89-104.

38 Sprince N L, Mark E J. An elderly woman with mild rheumatoid arthritis and progressive pulmonary fibrosis. Case records of the Massachusetts General Hospital. N Engl J Med 1982; 306: 157-66

39 D'Angelo W A, Fries J F, Masi A T, Shulman L E. Pathologic음 observations in systemic sclerosis (scleroderma). Am J Med 1969; 46: 428-40.

40 Fortoul T I, Cano-Valle F, Oliva E, Barrios R. Follicular bronchiolitis in association with connective tissue diseases. N Lung 1985; 163: 305-14. 